\title{
Estrogen Receptor Positive by Immunohistochemistry 71-80 Percent
}

National Cancer Institute

\section{Source}

National Cancer Institute. Estrogen Receptor Positive by Immunohistochemistry 71-80

Percent. NCI Thesaurus. Code C141474.

An immunohistochemical staining finding indicating that 71-80 percent of the cells in a tissue sample are expressing estrogen receptor. 